\title{
Chapter 13 \\ Article 5: The Right to Parental Guidance \\ Consistent with the Evolving Capacity of the Child
}

\author{
Gerison Lansdown
}

States Parties shall respect the responsibilities, rights and duties of parents or, where applicable, the members of the extended family or community as provided for by local custom, legal guardians or other persons legally responsible for the child, to provide, in a manner consistent with the evolving capacities of the child, appropriate direction and guidance in the exercise by the child of the rights recognized in the present Convention.

\section{What Did Children Say?}

'Governments can help, support families, plan visits by social workers. Have a closer follow-up. Children should participate in specific projects (with the presence of parents).' (Western Europe/Other)

'Parents' role is to provide food, affection, love, education, protection and clothing.' (Western Europe/Other)

'Does the government offer aid ("monetary or professional, for example social workers", to parents and children?' (Western Europe/Other)

'The State should intervene when children are in danger.' (Western Europel Other)

\footnotetext{
G. Lansdown $(\bowtie)$

Carleton University, Ottawa, ON, Canada 


\section{Overview}

Article 5 is a unique provision in international human rights law, introducing a triangular relationship of responsibilities and accountabilities between the child, the child's parents or caregivers, and the state (Vučković-Šahović et al., 2012, pp. 155-164). It underwent radical transformation during the Convention drafting process. The original Polish draft contained no provision covering the issues addressed in Article 5 (Office of the United Nations High Commissioner for Human Rights and Rädda barnen (Society: Sweden), 2007, p. 357). Subsequent proposals were put forward to introduce a focus on the autonomy of the family and respect for their rights and responsibilities (Office of the United Nations High Commissioner for Human Rights and Rädda barnen (Society: Sweden), 2007, p. 358), reflecting existing provisions in other treaties. ${ }^{1}$

Further debate highlighted the imperative for a clearer focus on the rights of the child and led to the introduction of recognition that parents' rights and duties must reflect and be provided in accordance with the child's rights and their evolving capacities. In other words, the exercise of parental responsibilities must reflect the gradual capacity of the child to take increasing responsibilities for themself (UN Committee on the Rights of the Child, 2009, paras. 84, 85). Parental guidance, accordingly, must be appropriate, and directed towards the exercise by the child of the rights contained in the Convention. The inclusion of this provision, while maintaining recognition of the right of parents to protection from arbitrary interference from the state, also places boundaries on the exercise of arbitrary control over the child by their parents (Office of the United Nations High Commissioner for Human Rights and Rädda barnen (Society: Sweden), 2007, p. 359). It thereby affords the state a role in protecting the child in line with the rights embodied in the Convention.

The concept of evolving capacities introduces a framework for recognition that the Convention, in its entirety, obliges States Parties create an environment to ensure:

- Respect for the child's evolving capacities, recognising the child as a subject of rights, with gradual and increasing agency in exercising those rights for themself

- Protection of the child from exposure to risks inappropriate to their level of capacity

- Fulfilment of the child's optimum capacities (Lansdown, 2005, p. 15).

\footnotetext{
${ }^{1}$ See, for example, articles 18 and 23 of the International Covenant on Civil and Political Rights and article 10 of the International Covenant on Economic, Social and Cultural Rights.
} 


\section{General Principles}

Article 2 The evolving capacities principle must be applied without discrimination. The Committee has consistently argued, for example, that there must be no discrimination in the setting of minimum age limits between boys and girls (2005, para. 19). It also highlights that children with disabilities can experience over-protection, leading to denial of both recognition of evolving capacities and opportunities to acquire increasing autonomy, and requires States Parties to adopt measures to address both direct and indirect discrimination in that regard (2007a).

Article 3 The rights and duties of parents derive from their responsibilities to act in the best interests of the child. This obligation is affirmed in Article 18, which states that the best interests of the child will be parents' basic concern, and necessitates that parents adjust the levels of guidance and support in accordance with the evolving capacities of the child. The evolving capacities of the child need to inform the determination of a child's best interests (UN Committee on the Rights of the Child, 2013).

Article 6 Article 5 affirms that appropriate parental guidance, consistent with respect for children's evolving capacities and directed to the exercise by the child of their rights, is necessary to promote the optimum development of the child. The Committee highlights obligations on States to contribute to the capacity of parents to fulfil this goal (2006).

Article 12 The right to express views and have them afforded due weight in accordance with age and maturity, as elaborated in Article 12, reaffirms the recognition of the importance of acknowledging the evolving capacities of the child. While all rights in the Convention apply to all children, Articles 5 and 12 testify to the importance of acknowledging that the nature of implementation, and that the active role of children in the realisation of rights, will vary in accordance with evolving capacities.

\section{Articles Related to or Linked to Article 5}

The concept of evolving capacities is relevant to the exercise of all rights but has particular relevance in respect of the following articles.

Article 1 defines a child as 'every human being below the age of eighteen years' and within that definition, Article 5 requires that legislation and practice must take account of the child's 'evolving capacities.'

Article 9 acknowledges the rights of parents not to be separated from a child unless in a child's best interests.

Article 14 requires that parents provide direction to the child in the exercise of his or her right in a manner consistent with the evolving capacities of the child. 
Article 18 recognises the principle of parental responsibilities for bringing up their children.

\section{Relevant Instruments}

No other human rights treaty has a directly comparable provision to Article 5, but its origins derive from and are reflected in recognition of the role of the family as the natural and fundamental group unit of society, in the following treaties:

- UN Universal Declaration of Human Rights (1948), Article 16 (3)

- International Covenant on Civil and Political Rights (1966), Articles 18 \& 23

- International Covenant on Economic, Social and Cultural Rights (1966), Articles 10

- UN Convention on the Elimination of All Forms of Discrimination against Women (1979), Article 16

- UN Convention on the Rights of Persons with Disabilities (2006), Article 23

\section{Attributes}

\section{Attribute One: Respect for the Primacy of Parents and Comparable Care Givers}

Article 5 reaffirms the general principle that States Parties must respect the primacy of parents in the upbringing of their children. In so doing, it recognises the responsibilities, rights, and duties of parents, and the consequent boundaries on the arbitrary intervention of the state into family life (Office of the United Nations High Commissioner for Human Rights and Rädda barnen (Society: Sweden), 2007, p. 359). This focus is consistent with the emphasis in the Convention of the family as the fundamental group of society, the natural environment for growth and well-being, and the need for necessary protection and assistance to enable families to assume their responsibilities (UN Committee on the Rights of the Child, 2003, para. 14; UN General Assembly, 1990, sec. preamble).

Article 5 extends responsibilities, rights and duties, where applicable, to other members of the extended family or community where they are recognised by local custom, as well as legal guardians and other persons legally responsible for the child, thereby acknowledging that children can be cared for through many different arrangements. This can include, for example, the nuclear family, extended family, and other traditional and modern community-based arrangements, all of which are valid 'provided they are consistent with children's rights and best interests' (UN Committee on the Rights of the Child, 2006, para. 15). This flexible definition of the family is emphasised in a General Comment of the Human Rights Committee 
as being 'interpreted broadly to include all persons composing it in the society of the State Party concerned' (United Nations, 2006, p. 184). Whatever form of family is recognised in a given society must be afforded the protections embodied in Article 23 of the International Covenant on Civil and Political Rights by the State Party (United Nations, 2006, p. 188).

Parental responsibilities, rights, and duties are not defined in either the International Covenant on Civil and Political Rights or the Convention on the Rights of the Child, but Article 5 makes clear that they are not absolute or inalienable. They derive from the obligation to act in the best interests of the child and to enable the exercise by the child of their rights.

\section{Attribute Two: Appropriate Direction and Guidance}

The direction and guidance that parents or other caregivers provide for children is qualified through three provisions. First, it must be appropriate. In this context, appropriate direction and guidance necessitates that it is provided in a manner consistent with the rights embodied in the Convention. Accordingly, parents cannot treat the child in ways that would serve to violate or neglect their rights, nor justify such behaviours on grounds of traditional cultures (UN Committee on the Rights of the Child, 1995, paras. 7, 13; UNICEF, 2007). The Committee has emphasised the importance of ensuring the balance between parental authority and the rights of the child (1994a, p. 63). States Parties must provide legislative and policy frameworks to ensure protection of the child from violations of their rights within the family. ${ }^{2}$

Second, direction and guidance must be provided in a manner consistent with the child's evolving capacities, and 'through dialogue, negotiation and participation' (UN Committee on the Rights of the Child, 1994b, para. 183 et seq, 2003, para. 7). Finally, it must be directed to the 'exercise by the child of (their) rights.' This provision highlights the child as a subject of rights. In other words, the role of parental guidance is to promote the agency of the child to claim their own rights, while providing the necessary protection in accordance with the child's evolving capacities. The Committee has encouraged States Parties to provide comprehensive support and education programmes to promote this understanding of parenthood (2006, paras. 20-21).

\footnotetext{
${ }^{2}$ See, for example, General Comment no. 13 (UN Committee on the Rights of the Child, 2011, paras. 38-44), and General Comment no. 8 (UN Committee on the Rights of the Child, 2007b, para. 22).
} 


\section{Attribute Three: Evolving Capacities of the Child}

Although Article 5 has not been formally identified by Committee as one of the General Principles to be applied in the realisation of all other rights, the concept of the evolving capacities of the child is recognised as 'an enabling principle that addresses the process of maturation and learning through which children progressively acquire competencies, understanding and increasing levels of agency to take responsibility and exercise their rights' (UN Committee on the Rights of the Child, 2016). It recognises the child, irrespective of age, as an active participant in their own development, entitled to be afforded opportunities for the gradual acquisition of greater autonomy (UN Committee on the Rights of the Child, 2006, para. 14).

Article 5 can be understood to complement Article 12, the right of children to be heard in matters affecting them, by acknowledging the transfer of the exercise of rights from parents to children as they acquire sufficient maturity. It avoids the need for imposition of arbitrary universal age limits and acknowledges that the child must be respected to take increasing levels of responsibility consistent with their capacities. The exercise of parental rights and responsibilities must reflect children's evolving capacities in respect of the exercise of all rights in the Convention. Although, in addition to Article 5, the concept of evolving capacities is only specifically referenced in Article 14, it must be understood as having application in the realisation of all other rights. ${ }^{3}$

With regard to a number of Convention rights, the Committee recommends that States Parties consider the introduction of legal age limits, to protect children from premature exposure to the full responsibilities of adulthood (for example, child labour, marriage, use and sale of tobacco and alcohol) while ensuring appropriate respect for their emerging capacities (for example, consent to adoption, medical consent, access to sexual and reproductive health services) (2016, para. 20). At the wider policy level, the Committee also encourages recognition of the role of children themselves as active agents in both identification of risk and potential programmes to promote protection (2016, para. 19).

\section{References}

Lansdown, G. (2005). The evolving capacities of the child. UNICEF Innocenti Research Centre. Office of the United Nations High Commissioner for Human Rights \& Rädda barnen (Society: Sweden). (2007). Legislative history of the convention on the rights of the child (Vol. 1-2). United Nations. https://digitallibrary.un.org/record/602462? $1 \mathrm{n}=\mathrm{en}$

\footnotetext{
${ }^{3}$ During discussion on Article 15, the right to freedom of association and assembly, the Working Group drafting the Convention argued against a reference to the evolving capacities of the child on the basis that a generic article would encompass the principle with application across all provisions of the Convention (Office of the United Nations High Commissioner for Human Rights and Rädda barnen (Society: Sweden), 2007, p. 467).
} 
UN Committee on the Rights of the Child. (1994a). Report on the 5th session, 10-28 January 1994, $C R C / C / 24$. Retrieved October 12, 2020, from https://digitallibrary.un.org/record/193291? $\ln =\mathrm{en}$

UN Committee on the Rights of the Child. (1994b). Report on the 7th session, Geneva, 26 September-14 October 1994, CRC/C/34. Retrieved October 12, 2020, from https:// digitallibrary.un.org/record/183427? $1 n=$ en

UN Committee on the Rights of the Child. (1995). Concluding observations: Holy See, Nov 27, 1995, CRC/C/15/Add.46. Retrieved October 11, 2020, from https://digitallibrary.un.org/ record $/ 210287 ? \ln =\mathrm{en}$

UN Committee on the Rights of the Child. (2003). General Comment No. 4 (2003) Adolescent health and development in the context of the Convention on the Rights of the Child, July 1, 2003, $C R C / G C / 2003 / 4$. Retrieved October 12, 2020, from https://digitallibrary.un.org/record/503074? $\ln =\mathrm{en}$

UN Committee on the Rights of the Child. (2005). General Guidelines regarding the form and content of periodic reports to be submitted by States parties under article 44, paragraph 1 (b) of the Convention, June 3, 2005, CRC/C/58/Rev.1. Retrieved October 12, 2020, from https:// digitallibrary.un.org/record/575788? $1 \mathrm{n}=\mathrm{en}$

UN Committee on the Rights of the Child. (2006). General Comment No. 7 (2005) Implementing child rights in early childhood, September 20, 2006, CRC/C/GC/7/Rev.1. Retrieved October 12, 2020, from https://digitallibrary.un.org/record/584854? ln=en

UN Committee on the Rights of the Child. (2007a). General Comment No. 9 (2006) The rights of children with disabilities, November 13, 2007, CRC/C/GC/9. Retrieved October 12, 2020, from https://digitallibrary.un.org/record/593891? ln=en

UN Committee on the Rights of the Child. (2007b). General Comment No. 8 (2006) The right of the child to protection from corporal punishment and other cruel or degrading forms of punishment (arts. 19; 28, para. 2; and 37, inter alia), March 2, 2007, CRC/C/GC/8. Retrieved October 12, 2020, from https://digitallibrary.un.org/record/583961? $\ln =\mathrm{en}$

UN Committee on the Rights of the Child. (2009). General Comment No. 12 (2009) The right of the child to be heard, July 20, 2009, CRC/C/GC/12. Retrieved October 12, 2020, from https:// digitallibrary.un.org/record/671444? $1 n=$ en

UN Committee on the Rights of the Child. (2011). General Comment No. 13 (2011) The right of the child to freedom from all forms of violence, April 18, 2011, CRC/C/GC/13. Retrieved October 12, 2020, from https://digitallibrary.un.org/record/711722? $\ln =\mathrm{en}$

UN Committee on the Rights of the Child. (2013). General Comment No. 14 (2013) On the right of the child to have his or her best interests taken as a primary consideration (art. 3, para. 1), May 29, 2013, $C R C / C / G C / 14$. Retrieved October 12, 2020, from https://digitallibrary.un.org/record/ $778523 ? \ln =\mathrm{en}$

UN Committee on the Rights of the Child. (2016). General Comment No. 20 (2016) on the implementation of the rights of the child during adolescence, December 6, 2016, CRC/C/GC/ 20. Retrieved October 12, 2020, from https://digitallibrary.un.org/record/855544? $1 \mathrm{n}=\mathrm{en}$

UN General Assembly. (1990). Convention on the rights of the child, 1990, A/RES/45/104. Retrieved April 19, 2020, from https://digitallibrary.un.org/record/105613? $1 \mathrm{n}=\mathrm{en}$

UNICEF. (2007). Implementation Handbook for the Convention on the Rights of the Child (3rd ed.). UNICEF. Retrieved April 19, 2020, from https://www.unicef.org/publications/index_ 43110.html

United Nations. (2006). Compilation of general comments and general recommendations adopted by human rights treaty bodies, HRI/GEN/1/Rev. 8. UN. Retrieved April 19, 2020, from http:// digitallibrary.un.org/record/576098

Vučković-Šahović, N., Doek, J. E., \& Zermatten, J. (2012). The rights of the child in international law: Rights of the child in a nutshell and in context: All about children's rights. Stämpfli. 
Open Access This chapter is licensed under the terms of the Creative Commons Attribution 4.0 International License (http://creativecommons.org/licenses/by/4.0/), which permits use, sharing, adaptation, distribution and reproduction in any medium or format, as long as you give appropriate credit to the original author(s) and the source, provide a link to the Creative Commons license and indicate if changes were made.

The images or other third party material in this chapter are included in the chapter's Creative Commons license, unless indicated otherwise in a credit line to the material. If material is not included in the chapter's Creative Commons license and your intended use is not permitted by statutory regulation or exceeds the permitted use, you will need to obtain permission directly from the copyright holder. 